\title{
REVOLUÇÃO GENÔMICA: UMA SEQUÊNCIA DIDÁTICA PARA CONTEXTUALIZAR O ENSINO DE GENÉTICA NO ENSINO FUNDAMENTAL DENTRO DE UMA PERSPECTIVA CTSA
}

\author{
Patrícia Bastos Leonor ${ }^{1}$, Helania Mara Grippa Rui² \\ Manuella Villar Amado ${ }^{3}$, Sidnei Quezada Meirelles Leite ${ }^{4}$ \\ Programa de Pós-graduação em Educação em Ciências e Matemática \\ Instituto Federal do Espírito Santo - Campus Vitória \\ Avenida Vitória, 1729 - Jucutuquara, Vitória, Espírito Santo. CEP 29040780.
}

\begin{abstract}
RESUMO
O presente trabalho constitui-se em um estudo de caso da aplicação de uma Sequencia Didática ao se utilizar revistas, jornais e o filme "prova de amor", para ensinar conteúdos de genética básica dentro de uma perspectiva CTSA em uma turma de oitavo ano de uma escola pública no município de Vitória do Estado do Espírito Santo. A sequência didática foi baseada na proposta metodológica dos Três Momentos Pedagógicos baseadas em Demétrio Delizoicov, José Angotti e Martha Pernambuco, usando a exibição do filme e da realização de um júri simulado. Os resultados apontaram que os alunos se apropriaram de muitos conceitos relativos à genética mostrando-se capazes de promover uma discussão do papel da ciência na sociedade com reflexões críticas pautadas nos valores sociais vigentes. Sendo assim, acreditamos que a SD "Revolução Genômica" proposta nesse trabalho foi validada através da aplicação em sala de aula e avaliação dos pares.
\end{abstract}

Palavras-chave: ensino de ciências, ensino de genética, ensino fundamental, sequência didática.

\begin{abstract}
This paper presents a case study on the application of a Teaching Sequence when using magazines, newspapers and the movie "proof of love" to teach basic genetic content within a Science-Technology-Society-Environment (STSE) perspective in a class of eighth year of a public school in Vitória of Espírito Santo State of Brazil. This didactic sequence was based on methodological proposal of Three Moments Pedagogical based Demetrius Delizoicov, Joseph Angotti and Martha Pernambuco, using the screening and conducting a mock jury. The results showed that students appropriated many concepts related to genetics showing themselves capable of promoting a discussion of the role of science in society with critical reflections that were based on prevailing social values. Accordingly, we believe that the didactic sequence "Genomic Revolution" proposed in this work was validated through application in classroom and peer assessment.
\end{abstract}

Keywords: science education, genetics teaching, basic education, didactic sequence.

\footnotetext{
1Professora de Ciências, Mestre em Educação em Ciências e Matemática. Secretaria Municipal de Educação de Vitória - ES. E-mail: patriciabl5@yahoo.com.br

2 Professora de Ciências, Mestre em Educação em Ciências e Matemática. Secretaria Municipal de Educação de Aracruz - ES. E-mail: helaniamara@hotmail.com

3 Professora de Educação em Ciências Biologias, D.Sc. - Docente do Programa de Pós-graduação em Educação em Ciências e Matemática, Instituto Federal do Espírito Santo. E-mail: manuellaamado@gmail.com

4 Professor de Educação em Ciências Químicas, D.Sc. - Docente do Programa de Pós-graduação em Educação em Ciências e Matemática, Instituto Federal do Espírito Santo. E-mail: squezada@ifes.edu.br 


\section{INTRODUÇÃO}

Os conceitos e termos de genética se fazem presentes na mídia e na cultura popular mediante produções como jogos, filmes e programas de TV sensacionalistas que efetuam testes de DNA. Sendo assim, este tema não está muito distante de nossos alunos que possuem acesso a estes recursos e assistem desenhos animados onde heróis e vilões se estabeleceram graças a mutações genéticas e à engenharia genética.

O pai da genética moderna é um monge austríaco chamado Gregor Mendel que publicou suas descobertas em 1865. De lá para cá, muita coisa já foi realizada, após a identificação da molécula de DNA: decifração do código genético pelo Projeto Genoma Humano, criação de transgênicos e clonagem. Dentre os benefícios da engenharia genética, segundo Barth (2005), podemos hoje contar com remédios "sob medida", terapia gênica, terapia com células- tronco, testes de paternidade e na área forense, mapeamento e planejamento genético e escolha do sexo de embriões. Estes avanços demandam reflexões, pois existem limites técnicos e éticos a serem respeitados. Barth (2005) informa que na declaração da UNESCO, o genoma humano é citado como patrimônio da humanidade ressaltando a importância da preservação da vida e da dignidade humana. Para ele:

\footnotetext{
As possibilidades técnicas obrigam a repensar os valores éticos e orientar as ações da ciência nas suas várias especializações. A ciência cria, inventa, inova; a bioética procura salvaguardar os interesses humanos e a vida, chamando em causa os valores e recordando o dever da responsabilidade e da prudência. (BARTH, 2005, p.390)
}

Há bem pouco tempo este assunto era classificado como "complexo" para as turmas da faixa etária de 12 e 13 anos dos 8o anos, porém com os citados avanços e as orientações de documentos como os PCN, ciência e tecnologia passaram a ser incluídas nos currículos do ensino fundamental. A proposta da utilização de textos de jornais e revistas sobre o tema e do recurso audiovisual como problematização, visa aproximar os estudantes desta temática, inserindo-os também em debates sobre ética, ciência e cidadania, discutindo os limites necessários para nossas escolhas, que serão vivenciadas na vida em sociedade. Percebe-se que o uso de material audiovisual tem sido amplamente difundido nos diversos níveis de ensino, que de certa forma tem facilitado o processo de ensino-aprendizagem. Sendo assim, as animações, documentários e vídeos produzidos especialmente para uso em salas de aula têm 
se multiplicado, mas o acesso a esses materiais nem sempre é possível, contudo, filmes comerciais são muito utilizados na área de Ciências Biológicas, como alternativa para tratar tanto de assuntos relacionados à saúde quanto à educação.

O presente trabalho objetivou analisar a validação de uma sequência didática construída a partir do modelo dos Três Momentos Pedagógicos proposto por Demétrio Delizoicov, José Angotti e Martha Pernambuco (2002), para ensinar conteúdos de genética básica dentro de uma perspectiva CTSA em uma turma de $8^{\circ}$ ano de uma escola pública no município de Vitória do Estado do Espírito Santo.

\section{PROCEDIMENTOS METODOLÓGICOS}

O presente trabalho é uma pesquisa de caráter qualitativo do tipo estudo de caso que visa validar uma sequência didática (SD) sobre o ensino de genética e sua relação com a cidadania a partir da aplicação em sala de aula e avaliação feita por pares segundo procedimento proposto por Guimarães e Giordan (2011). Segundo Ludke e André(1986), a pesquisa qualitativa pode assumir várias formas, destacando-se, principalmente, a pesquisa etnográfica e o estudo de caso. Ambas vêm ganhando muita aceitação e credibilidade na área da educação, mais precisamente para investigar questões relacionadas com a escola. Segundo as autoras, o estudo de caso deve ser aplicado quando o pesquisador tiver o interesse em pesquisar uma situação singular, particular ressaltando que o caso é sempre bem delimitado, devendo ter seus contornos claramente definidos no desenvolver do estudo.

Um estudo de caso, de acordo com Ludke e André (1986), possui as seguintes características: (1) visam a descoberta; (2) enfatizam a interpretação em contexto; (3) retratam a realidade de forma completa e profunda; (4) usam uma variedade de fontes de informação; (5) permitem generalizações naturalistas; (6) procuram representar as diferentes perspectivas presentes numa situação social; (7) utilizam uma linguagem e uma forma mais acessível do que os outros relatórios de pesquisa. A SD foi baseada na proposta metodológica dos três momentos pedagógicos de Delizoicov et al. (2002), que são identificados como problematização (P), organização do conhecimento (OC) e aplicação do conhecimento (AC), que se opõe à prática tradicional memorística do ensino. Segundo estes autores, a problematização intenciona que os alunos sejam desafiados a expor seus conhecimentos prévios e reflexões sobre a temática, permitindo que o aluno sinta a necessidade de aquisição do conhecimento para enfrentar o 
problema. A organização do conhecimento dá-se através da seleção e organização dos conhecimentos necessários para a compreensão dos temas e da problematização inicial, que pode acontecer por meio de atividades diversas. Já a aplicação do conhecimento pretende "capacitar os alunos ao emprego dos conhecimentos, no intuito de formá-los para que articulem constante e rotineiramente, a conceituação científica com situações reais" (DELIZOICOV et al., 2002, p. 202).

A aplicação da SD foi realizada na Escola Municipal de Ensino Fundamental Suzete Cuendet, localizada na Rua Otto ramos, número 69, Maruípe, Vitória, Espírito Santo. Os sujeitos envolvidos foram alunos de uma turma do $8^{\circ}$ ano do ensino fundamental matutino composta por 33 alunos. A avaliação por pares ocorreu durante as aulas da disciplina Debates Conceituais em Ciências do Programa de Educação em Ciências e Matemática do IFES (Educimat) envolvendo oito professores da área de ciências. Para análise, avaliação e validação de sequências didáticas foram utilizados os pressupostos proposto por Guimarães e Giordan (2011) que emprega um critério de suficiência com intervalo de 1 a 5.0 instrumento que avalia a qualidade das sequências didáticas (SD) conforme é formado por quatro categorias: Estrutura e Organização - item que observa a organização da sequência didática, sua clareza, redação, tempo e metodologias de aplicação, explicações para seu desenvolvimento e seus referencias teóricas; Problematização - num contexto pedagógico, problematização é uma ação que tem como objetivo o desenvolvimento do aluno. A noção do problema cria uma situação de reflexão para os sujeitos solucionarem conflitos. Problematizar é proporcionar uma abordagem contextualizada sobre um assunto, uma condição que promove o interesse do educando,que se sente desafiado a utilizar seu conhecimento na tentativa de resolver situações problematizadoras bem colocadas, construindo explicações adequadas; Conteúdos e Conceitos - atenção aos conceitos, mas também ás relações com o conhecimento coloquial e a organização lógica dos conteúdos para a construção de conceitos significativos, sustentando a resposta do problema, alcançando os objetivos propostos de acordo com as ações educativas; Metodologias de Ensino e Avaliação - categoria que dirige a atenção à organização para o desenvolvimento das situações de aprendizagem e avaliação, para que alcancem os objetivos das sequências didáticas. 


\section{RESULTADOS E DISCUSSÃO}

A SD (Anexo) foi organizada tendo como problematização reportagens de jornais e a exibição do filme "Prova de amor" levantando questionamentos e promovendo a investigação. Já na fase seguinte, a organização do conhecimento foi proporcionado pela aula expositiva dialogada, experimentação da extração do DNA, pesquisas no laboratório de informática, entrevistas a oncologistas e geneticistas, com produção de relatórios e textos. A execução do júri simulado sobre o filme compreende a aplicação do conhecimento onde os alunos representam papéis sociais como: advogado, assistentes sociais e médicos.

O filme foi exibido na lousa digital do laboratório de informática, em duas sessões, com pausa na sequência da audiência jurídica, de forma que a turma não assistiu ao final do filme nesse primeiro momento para que não houvesse interferência no julgamento de valores morais e éticos proposto pelo júri simulado, que seria realizado a seguir. 0 filme conta a história de Anna Fritzgerald, um bebê geneticamente projetado para ser doadora compatível com sua irmã, Kate, doente de câncer. Por 11 anos, ela foi submetida a inúmeras consultas médicas, cirurgias e transfusões para que sua irmã mais velha, Kate, pudesse de alguma forma, lutar contra a leucemia que a atingiu ainda na infância. Tudo transcorre normalmente até que Anna contrata um advogado famoso, para conseguir a emancipação médica dos pais. Logo após a semana de exibição da primeira parte do filme, conceitos de genética básica, bioética, transplante de órgãos e de medula óssea, compatibilidade sanguínea e histológica, leucócitos, emancipação médica, leucemia, leucemia pró-mielocítica aguda, bebês projetados, fertilização artificial, dentre outros, foram pesquisados pelos alunos através de livros especializados, sites da internet e por entrevistas a profissionais de saúde, como forma de buscar informações relevantes, para embasar argumentos com conhecimentos científicos e jurídicos durante o júri simulado.

Na extração do DNA a turma foi dividida em pequenos grupos para a realização de uma prática experimental investigativa de extração do DNA do morango que proporcionou aos alunos a apropriação de conhecimentos sobre a estruturas do DNA,a além de outros como o manejo de materiais de laboratório e alguns conteúdos relativos a à química como solubilidade, separação de misturas e ligações químicas. 
O júri simulado realizou-se também no laboratório de informática da escola, com a participação da mediadora e professora de ciências. A turma se dividiu em dois grupos: um representando a menina Anna Fritzgerald, que no filme processa seus pais pelo direito de emancipação médica e outro, representando a mãe, Sara Fritzgerald, que busca a todo custo, salvar sua filha mais velha, doente de câncer. Cada grupo possuía um médico, um advogado e um assistente social, papel representado pelos próprios alunos para mediação das discussões.

Os jurados foram representados pelas professoras de ciências e informática e mais dois alunos. Após o júri simulado os alunos terminaram de assistir o restante do filme. Os alunos foram avaliados tomando-se como critério a unidade e a participação em grupo, a habilidade de argumentação, embasamento teórico e apropriação dos conteúdos de biologia em questão, relatórios, produção de textos, dando ênfase a leitura e a escrita. Desde a proposição das reportagens, experimento da extração do DNA do morango, exibição do filme em questão, percebemos o interesse diferenciado dos alunos, ficando evidenciada a sensibilidade dos alunos aos sintomas manifestado pela doente, e a reflexão sobre o comportamento de adolescentes que passam por conflitos emotivos. A maioria destes alunos no júri simulado se posicionou a favor de Anna desde o início, solidarizando-se com a busca de autonomia e liberdade com o próprio corpo, mas também evidenciando a típica rebeldia desta faixa etária contra a autoridade seus pais. A cena da família na praia comoveu a todos; percebe-se aqui a importância dos laços familiares numa clientela em que os lares, em sua maioria, foram dilacerados. Percebemos durante o processo que a pesquisa realizada por eles fundamentou os debates, conforme observamos nos quadros seguintes:

Os alunos foram provocados quanto à situação psicossocial dos outros filhos do casal Fritzgerald. Ao que uma aluna que representava uma assistente social, afirmou:

"O Jess apresenta dislexia por causa do abandono dos pais"

Foi imediatamente interpelada:

"Que nada, isto é genético! A criança nasce com este problema" e deu explicações sobre a doença. Um aluno pergunta:

"O que é dislexia?

Outro responde:

“Meu irmão apresentou dificuldades de ler escrever e a escola falou que ele tinha dislexia, que é uma dificuldade em identificar as letras." 
Também ficou evidente durante o processo que a pesquisa realizada pelos alunos fundamentou os debates, conforme observamos nos quadros seguintes:

Durante o júri, o advogado de Anna Fritzgerald questiona a médica do grupo contrário sobre a necessidade do transplante de medula, e obtém a seguinte resposta: "A leucemia ocorre em todas as faixas etárias, aumentando com a idade, entre 45 a 55anos, mais no sexo masculino. $O$ transplante de medula é um recurso terapêtico que aumenta a sobrevida em cinco anos ou mais se o diagnóstico for precoce."

Um dos jurados pergunta o que é translocação. A médica do grupo que representa a mãe de Anna, responde: “Ocorre ali uma mudança nos cromossomos 15 e 17; uma perninha de um passa para o outro, causando a doença."

Durante o júri simulado os alunos foram provocados a explicar e contextualizar questões como a fertilização artificial, como nasce um bebê projetado e quais foram as implicações sócio-afetivas desta doença no seio da família Fritzgerald. 0 fato dos pais de Kate optarem por um bebê projetado para salvar sua vida, levou a discussão sobre bioética, sobre os sentimentos e pensamentos dos alunos acerca desta questão. Muitos se colocaram no lugar da adolescente Anna, que tem consciência de sua situação: um ser que foi geneticamente selecionado para ser compatível com a irmã. A bioética tem por objetivo associar a biologia à ética, por meio de uma prática interdisciplinar, onde médicos juristas, advogados, cientistas, religiosos, atuem em comum acordo para estabelecer um conjunto de normas aceitável para todos e isto decorre dos avanços consideráveis da medicina e da biologia na atualidade.

Parece que se fará Alfabetização Científica quando o ensino de ciências contribuir para a compreensão de conhecimentos, procedimentos e valores que permitam aos estudantes tomar decisões e perceber tanto as muitas utilidades da ciência e suas aplicações na melhoria da qualidade de vida, quanto as limitações e consequências negativas de seu desenvolvimento (CHASSOT, 2001, p.99).

Para este autor, o desafio de discutir-se a ética nestes casos não é individual, mas pertinente à toda a sociedade, que tem o direito de estar informada o suficiente para debater determinadas 
questões como transgênicos, armamento nuclear, dentre outras. Dessa forma a SD desenvolvida nesse estudo está dentro da perspectiva do ensino de ciências da atualidade que abrange discussões pertinentes ao eixo CTSA, visando a formação de um aluno que saiba ler o mundo em seu entorno e contribuir de forma crítica e racional como membro atuante da sociedade.

Após os trabalhos desenvolvidos, o próximo passo seria a exposição e divulgação dos conhecimentos adquiridos através de uma mostra científica com a participação da comunidade na escola. Para tal, buscamos conhecer \investigar os saberes dos cidadãos \pessoas comuns sobre o tema genética e biotecnologia e a ciência como um todo, para que pudéssemos orientar nossas ações com base nestes conhecimentos. Sendo assim, os alunos se dividiram em grupos para entrevistar pessoas do entorno, parentes e conhecidos com as perguntas contidas no quadro abaixo.

1-O que é DNA, gene e cromossomo?

2-O que é transgênico?

3-O que é mutação?

4-O que são células- tronco?

5-O que pensa acerca dos avanços biotecnológicos como clonagem, bebês projetados, etc.

6-Para você deve haver um limite para os trabalhos e pesquisas científicas?

7-Você poderia apontar os benefícios advindos da genética e biotecnologia para a sociedade?

8-E prejuízos?

As entrevistas demonstram que algumas pessoas mais jovens com nível médio de escolarização, afirmam ter esquecido alguns conceitos; para a maioria, os avanços científicos são sempre positivos e não devem ser cerceados \limitados devido à sua estreita relação com o progresso; percebemos muitas distorções conceituais talvez advindas da mídia e suas estratégias sensacionalistas de divulgação de assuntos concernentes à ciência, e ainda aos filmes e desenhos animados e sua influência no imaginário das massas.

Os alunos foram avaliados tomando-se como critério a unidade e a participação em grupo, a habilidade de argumentação, embasamento teórico e apropriação dos conteúdos de biologia em questão, relatórios, produção de textos, dando ênfase à leitura e à escrita. Observamos através da aplicação da SD "Revolução Genômica" em sala de aula, que esta foi bem aceita 
pelos alunos e se mostrou eficiente em promover a motivação e a busca pelo conhecimento, tornando o processo de ensino aprendizagem agradável e promovendo alfabetização científica.

A validação pelos pares da SD proposta foi realizada pelos professores e colegas da disciplina Debates Conceituais em Ensino de Ciências do Programa Educimat, segundo os instrumentos de validação de sequências didáticas de Guimarães e Giordan (2011). A avaliação dos itens relacionados: aos métodos e abordagens para a resolução dos problemas; coerência; contextualização e conhecimento cientifico; conteúdos e conceitos conceituais, procedimentais, atitudinais, apontou que estes em grande parte a SD proposta atingiu seus objetivos tendo uma média de intervalo igual ou superior (4). Recebemos algumas recomendações como rever o encadeamento da sequencia didática proposta, explicitar os critérios de avaliação, organizar um momento de discussão para um feedback com os alunos, em termos de retorno das avaliações, e dividir a quantidade de conteúdos da segunda aula aplicada.

\section{CONCLUSÕES}

O ensino de ciências nos anos finais do Ensino Fundamental, bem como de todas as áreas de conhecimento vem apresentando uma série de desafios, como o desinteresse e desmotivação dos jovens aliados à questões de ordem social e política,a concorrência da Escola com a mídia, jogos e redes sociais, além das metodologias defasadas adotadas por esta instituição. Sendo assim, a proposta de abordagem temática em uma sequência didática que problematize e contextualize o cotidiano, que permita o desenvolvimento de práticas diversificadas que contemplem a participação de todos os alunos e a reflexão crítica acerca de ciência, tecnologia sociedade e melhoria da qualidade de vida, vem se contrapor ao ensino tradicional e memorístico que ainda acontece nas salas de aula.

Ao promover uma prática pedagógica com a utilização do cinema na sala de aula, ficou constatado que quando bem planejado a sua utilização e combinação com outras ferramentas como o júri simulado, estes se tornam importantes no processo ensino-aprendizagem. Sendo assim, os interesses dos alunos devem ser direcionados e motivados constantemente, buscando-se saber exatamente o que se quer que o aluno aprenda realmente e as possibilidades que se dispõem para que isso aconteça. 0 filme sozinho não abrange os 
conteúdos, como foi o caso da necessidade das pesquisas em laboratório de informática, para buscar novos subsídios para um assunto tão amplo, somente o filme, não daria conta de tantas respostas, reflexões, questionamentos sobre a genética, biotecnologia, engenharia genética, patrimônio genético, mas serviu para alavancar as indagações e principalmente a compreensão dos conceitos, tendo contribuído para muitas reflexões e múltiplas visões, além de propiciar uma autonomia de opiniões dos alunos dentro dos preceitos éticos e morais, que é o que se pretende na proposta de alfabetização científica. Dessa forma, acreditamos que a SD "Revolução Genômica" proposta nesse trabalho foi validada através da aplicação em sala de aula e avaliação dos pares. A validação fica evidente devido à participação ativa dos alunos nos debates do júri simulado, no empenho demonstrado na realização e análise das entrevistas, na efetiva aprendizagem dos referidos conteúdos e na avaliação positiva da proposta realizada pelos professores da área de ciências.

\section{AGRADECIMENTOS}

Os autores agradecem a colaboração dos professores mediadores do laboratório de informática que participaram ativamente no processo de realização deste trabalho, aos nossos alunos do $8^{\circ}$ ano da Escola Municipal de Aracruz-ES pelo compromisso e afinco no cumprimento das atividades propostas, à direção de nossas escolas e aos professores da disciplina Debates Conceituais em Ensino de Ciências do Mestrado Educimat-Ifes.

\section{REFERÊNCIAS}

BARTH, Wilmar Luiz. Engenharia Genética e Bioética. Teocomunicação, Porto Alegre, v.35, n.149, p.357-620, 2005.

CHASSOT, Áttico. Alfabetização científica: questões e desafios para a educação. Ijuí: Ed. Ijuí, 2001.

DELIZOICOV, Demétrio; ANGOTTI, José André; PERnAMBUCO, Marta Maria. Ensino de ciências: fundamentos e métodos. São Paulo: Cortez, 2002. 364 p.

GIORDAN,M.;GUIMARÃES,Y.A.F.;MASSI,L.Uma análise das abordagens investigativas de trabalhos sobre sequências didáticas:tendências no ensino de ciências.VIII ENPEC- Encontro Nacional de Pesquisas em Educação em Ciências.Campinas,2011.

LÜDKE, Menga e ANDRÉ, Marli E. D. A. Pesquisa em educação: abordagens qualitativas. São Paulo: EPU, 1986. 


\section{ANEXOS:}

\begin{tabular}{|l|l|}
\hline Planejamento da Sequência Didática \\
\hline Título: & REVOLUÇão GENÔMICA \\
\hline Público Alvo: & $\begin{array}{l}80 \text { anos(7a séries)/10 trimestre/ Escola Municipal de Ensino Fundamental, Vitória, Espírito } \\
\text { Santo. }\end{array}$ \\
\hline Problematização: & $\begin{array}{l}\text { Genética básica nos anos finais do Ensino Fundamental é um tema complexo e } \\
\text { dependendo da metodologia utilizada pelo professor pode se tornar maçante e } \\
\text { enfadonho. Sendo assim, propomos trabalhar os conteúdos de genética básica, através de } \\
\text { uma SD, dentro de uma perspectiva CTSA a partir da utilização de um filme comercial de } \\
\text { forma a promover reflexões como: Que questões éticas na atualidade estão relacionadas } \\
\text { à Genética? Que avanços e desafios as pesquisas sobre genética trouxeram para as } \\
\text { nossas vidas? }\end{array}$ \\
\hline Objetivos Gerais: & $\begin{array}{l}\text { - Compreender os conceitos relativos à genética, de forma a promover uma discussão do } \\
\text { papel da ciência na sociedade com reflexões criticas pautadas nos valores sociais vigentes. } \\
\text { - Refletir criticamente sobre situações atuais relacionadas à Genética; } \\
\text { - Construir conceitos relativos à genética, um júri simulado e a fim de promover } \\
\text { possibilidades de uma alfabetização científica. }\end{array}$ \\
\hline
\end{tabular}

\begin{tabular}{|c|c|c|c|}
\hline \multicolumn{4}{|c|}{ Conteúdos e Métodos } \\
\hline AULA & OBJETIVOS ESPECÍFICOS & CONTEÚDOS & DINÂMICA \\
\hline 1 & $\begin{array}{l}\text {-Relatar situações polêmicas } \\
\text { atuais relacionadas ao tema: } \\
\text { como teste de paternidade, } \\
\text { biotecnologia, inseminação } \\
\text { artificial, Transgênicos,etc.. }\end{array}$ & $\begin{array}{l}\text {-Doenças geneticamente determinadas; } \\
\text {-Fertilização artificial, transgênicos; } \\
\text {-Significado das palavras revolução e } \\
\text { genética; } \\
\text {-O que é revolução genômica? }\end{array}$ & $\begin{array}{l}\text {-Disponibilizar para os alunos } \\
\text { trechos de notícias de jornais, } \\
\text { revistas, desenhos, animações, } \\
\text { gibis, com situações polêmicas } \\
\text { envolvendo o tema. } \\
\text {-Levantar hipóteses sobre os } \\
\text { problemas como inseminação } \\
\text { artificial, teste de paternidade, } \\
\text { alimentos geneticamente } \\
\text { modificados, clonagem, etc. } \\
\text {-Mapear o conhecimento prévio } \\
\text { dos alunos: pedir que falem } \\
\text { sobre o tema, dúvidas, relatos. }\end{array}$ \\
\hline 2 e 3 & $\begin{array}{l}\text {-Conhecer o núcleo da } \\
\text { célula e identificar seus } \\
\text { componentes. } \\
\text {-Entender os conceitos de } \\
\text { genética e mecanismos. } \\
\text {-Conhecer o núcleo da } \\
\text { célula e identificar seus } \\
\text { componentes. } \\
\text {-Entender os conceitos de } \\
\text { genética e mecanismos de } \\
\text { herança. }\end{array}$ & $\begin{array}{l}\text { - O núcleo da célula; } \\
\text {-Divisão celular; } \\
\text {-Reprodução (mitose e meiose); } \\
\text {-Cromossomos, genes, DNA, e } \\
\text { mecanismos de herança; }\end{array}$ & $\begin{array}{l}\text {-Aula expositiva para trabalhar os } \\
\text { conceitos gerais de genética. } \\
\text {-Atividades } \\
\text {-correção de atividades }\end{array}$ \\
\hline 4 & $\begin{array}{lll}\text {-Realizar experimento } & \text { de } \\
\text { extração do DNA do } \\
\text { morango. }\end{array}$ & $\begin{array}{l}\text {-Solubilidade; } \\
\text {-Processos de separação de misturas, } \\
\text {-Manejo de materiais de laboratório, } \\
\text {-Medidas de volume, massa, } \\
\text { temperatura; } \\
\text {-Formação de precipitado; }\end{array}$ & $\begin{array}{l}\text {-Dividir a turma em grupos para } \\
\text { a realização de uma prática } \\
\text { experimental investigativa de } \\
\text { extração do DNA do morango } \\
\text {-Elaborar relatório com } \\
\text { questionamentos e conclusões. }\end{array}$ \\
\hline
\end{tabular}




\begin{tabular}{|c|c|c|c|}
\hline \multicolumn{4}{|c|}{ Conteúdos e Métodos } \\
\hline AULA & OBJETIVOS ESPECÍFICOS & CONTEÚDOS & DINÂMICA \\
\hline 5,6 e 7 & $\begin{array}{l}\text {-Analisar: } \\
\text { as causas e consequencias } \\
\text { da doença leucemia, } \\
\text {-os efeitos da doença em } \\
\text { um ambiente familiar, } \\
\text { bebês projetados, bioética. } \\
\text {-Promover discussões sobre } \\
\text { a adolescência. }\end{array}$ & $\begin{array}{l}\text {-Doenças geneticamente determinadas: } \\
\text { Leucemia, dislexia; } \\
\text {-Fertilizaçaõ artificial; } \\
\text {-Emancipaçãomédica; } \\
\text {-Biotecnologia; } \\
\text {-bioética; }\end{array}$ & $\begin{array}{l}\text {-Exibição do filme "Uma } \\
\text { prova de amor"até a cena do } \\
\text { julgamento. } \\
\text {-Escrever um texto sobre o tema. }\end{array}$ \\
\hline 8 & $\begin{array}{l}\text {-Pesquisar, procurando } \\
\text { entender os conceitos } \\
\text { relacionados ao filme. }\end{array}$ & $\begin{array}{l}\text {-Transplante de órgãos; } \\
\text {-Medula óssea; } \\
\text {-Compatibilidade sanguínea } \\
\text { histológica; } \\
\text {-Translocação cromossômica; } \\
\text {-Leucemia; }\end{array}$ & $\begin{array}{l}\text {-Aula no laboratório de } \\
\text { informática-pesquisa. } \\
\text {-Orientar os alunos na seleção } \\
\text { das informações, procurando } \\
\text { fontes confiáveis de pesquisa, } \\
\text {-Biblioteca. }\end{array}$ \\
\hline 9 & $\begin{array}{l}\text {-Pesquisar, procurando } \\
\text { entender os conceitos } \\
\text { relacionados ao tema. }\end{array}$ & $\begin{array}{l}\text {-Dislexia; } \\
\text {-Bebês projetados; } \\
\text {-Emancipação médica e legislação } \\
\text { brasileira; } \\
\text {-Biotecnologia; }\end{array}$ & $\begin{array}{l}\text {-Rever os conceitos registrados } \\
\text { na aula anterior. } \\
\text {-Aula no laboratório de } \\
\text { informática-pesquisa. }\end{array}$ \\
\hline 10 & $\begin{array}{l}\text {-Aplicação dos } \\
\text { conhecimentos através da } \\
\text { discussão do processo de } \\
\text { tomada de decisões. } \\
\text {-Compreender o que é } \\
\text { emancipação médica, } \\
\text {-Analisar os direitos do } \\
\text { doente de câncer e do } \\
\text { doador. }\end{array}$ & $\begin{array}{l}\text {-Emancipação médica e legislação; } \\
\text {-Bioética; } \\
\text {-Doadores; } \\
\text {-Higiene e segurança; }\end{array}$ & $\begin{array}{l}\text {-Organizar um júri simulado ou } \\
\text { usar a técnica da controvérsia, } \\
\text { criando diversos atores sociais } \\
\text { como: médicos, assistentes } \\
\text { sociais, jurados e advogados. }\end{array}$ \\
\hline 11 & $\begin{array}{l}\text {-Promover fechamento dos } \\
\text { debates do júri e assistir ao } \\
\text { final do filme. }\end{array}$ & -Bioética e direitos humanos; & $\begin{array}{l}\text {-Exibição do final do filme e } \\
\text { reflexão sobre as atividades. }\end{array}$ \\
\hline 12 & $\begin{array}{l}\text {-Promover entrevistas } \\
\text { gravadas a profissionais } \\
\text { da saúde,da genética e } \\
\text { pessoas comuns: } \\
\text {-Identificar outras doenças } \\
\text { relacionada genética, } \\
\text {-Identificar os tipos de } \\
\text { leucemia }\end{array}$ & $\begin{array}{l}\text {-Doenças determinadas } \\
\text { geneticamente; } \\
\text {-Tipos de leucemia; } \\
\text {-Formas de tratamento; } \\
\text {-O que faz um geneticista; } \\
\text {-Benefícios \prejuízos dos avanços da } \\
\text { biotecnologia; } \\
\text {-O que a população conhece \entende } \\
\text { do tema. }\end{array}$ & $\begin{array}{l}\text {-Promover entrevistas } \\
\text { gravadas a profissionais da } \\
\text { saúde, genética e pessoas } \\
\text { comuns: } \\
\text {-Visita ao Hospital. Santa Rita } \\
\text { de Cássia, ao Departamento de } \\
\text { genética da UFES, entrevista de } \\
\text { pessoas comuns( vizinhos, } \\
\text { transeuntes, etc).Em grupos. }\end{array}$ \\
\hline 13 & $\begin{array}{l}\text {-Conhecer o programa de } \\
\text { edição de vídeos do Linux } \\
\text {-Realizar a edição dos } \\
\text { vídeos em grupos. }\end{array}$ & $\begin{array}{l}\text {-Programa Kdenlive; } \\
\text {-Edição de vídeos; } \\
\text {-A linguagem midiática de um mini - } \\
\text { documentário; }\end{array}$ & $\begin{array}{l}\text {-Aula no laboratório de } \\
\text { informática com o professor } \\
\text { mediador. }\end{array}$ \\
\hline 14 e 15 & $\begin{array}{l}\text {-Conhecer o gêneros } \\
\text { textuais: } \\
\text { jornalístico\reportagem } \\
\text {-Escrever um texto do tipo } \\
\text { reportagem sobre o } \\
\text { conteúdo das entrevistas. }\end{array}$ & $\begin{array}{l}\text {-Gêneros textuais; } \\
\text {-Gênero de texto jornalístico; }\end{array}$ & $\begin{array}{l}\text { - Aula de português } \\
\text { Transformar as entrevistas em } \\
\text { texto jornalístico. }\end{array}$ \\
\hline
\end{tabular}




\begin{tabular}{|c|c|c|c|}
\hline \multicolumn{4}{|c|}{ Conteúdos e Métodos } \\
\hline AULA & OBJETIVOS ESPECÍFICOS & CONTEÚDOS & DINÂMICA \\
\hline 16 & $\begin{array}{l}\text { Analisar } \quad \text { o } r \text { material } \\
\text { produzido, a saber texto } \\
\text { jornalístico e vídeos para } \\
\text { divulgação dos resultados } \\
\text { em uma mostra. }\end{array}$ & $\begin{array}{l}\text {-Os saberes e reflexões dos cidadãos } \\
\text { entrevistados sobre o tema; } \\
\text {-Revolução Genômica: realmente } \\
\text { aconteceu? }\end{array}$ & $\begin{array}{l}\text {-Aula no laboratório de } \\
\text { informática : exibição dos vídeos } \\
\text { e textos para análise. }\end{array}$ \\
\hline 17 & $\begin{array}{l}\text {-Elaborar modelos de DNA } \\
\text { com diferentes materiais. }\end{array}$ & -Cromossomos, genes, DNA; & $\begin{array}{l}\text {-Confecção de modelos de DNA, } \\
\text { do núcleo, cromossomos }\end{array}$ \\
\hline 18 & \begin{tabular}{lr} 
Apresentar numa mostra \\
cultural os resultados dos \\
trabalhos & \multicolumn{2}{c}{ realizados, } \\
visando explicitar os \\
conceitos de genética de \\
interesse/déficit & de \\
conhecimentos & da \\
população/comunidade & \\
escolar.
\end{tabular} & $\begin{array}{l}\text {-O núcleo celular; } \\
\text {-Biotecnologia; } \\
\text {-Bioética; } \\
\text {-Transplantes e doação de órgãos; } \\
\text {-Leucemia e outras doenças } \\
\text { determinadas geneticamente; }\end{array}$ & $\begin{array}{l}\text {-Exposição de trabalhos: } \\
\text { modelos de célula, núcleo, } \\
\text { cromossomos e DNA, } \\
\text {-Divulgação dos resultados das } \\
\text { pesquisas e entrevistas, } \\
\text {-Divulgação de campanhas de } \\
\text { doação de órgãos e medula, e de } \\
\text { entidades relacionadas ao } \\
\text { tratamento o câncer. }\end{array}$ \\
\hline
\end{tabular}

\begin{tabular}{|c|c|}
\hline Avaliação & $\begin{array}{l}\text {-A avaliação será contínua durante todo o processo da sequencia } \\
\text { didática: desempenho no júri simulado seguindo critérios como } \\
\text { embasamento teórico e capacidade de argumentação, habilidade de } \\
\text { trabalhar em equipe;Empenho e qualidade durante as entrevistas; a } \\
\text { produção de textos e vídeos ; Prova escrita( é conteúdo programático) e } \\
\text { participação na mostra dos trabalhos; produção de relatórios da } \\
\text { atividade experimental e textos no decorrer do processo, relatórios. }\end{array}$ \\
\hline $\begin{array}{l}\text { Referencial } \\
\text { Bibliográfico: }\end{array}$ & $\begin{array}{l}\text {-Filme "Uma prova de amor", } \\
\text {-Pesquisa } \\
\text { www.inca.gov.br/ } \\
\text { www.cancer.org.br/ } \\
\text { www1.inca.gov.br/conteudo_view.asp?ID=125 } \\
\text { pt.wikipedia.org/wiki/Transplante_de_medula_óssea } \\
\text { www.abrale.org.br/doencas/transplante/index.php } \\
\text { www.clicrbs.com.br/portalsocial } \\
\text { www.adote.org.br/ } \\
\text { www.jornaldaciencia.org.br/Detalhe.jsp?id=26464 } \\
\text { www.istoe.com.br/.../191077_A+BEBE+PLANEJADA+PARA+CUR } \\
\text { HTTP://genoma.ib.usp.br/?page id=1362 } \\
\text { Livro: Projeto Radix Ciências - 8o Ano - 7á Série - 2009 - Editora } \\
\text { scipicione,Elizangela Andrade,Karina Pessôa,Leonel Favali }\end{array}$ \\
\hline Bibliografia consultada: & $\begin{array}{l}\text { - portal.saude.gov.br/portal/arquivos/.../Manual_Oncologia_2010.pdf } \\
\text { - DELIZOICOV, Demetrio ANGOTTI, Jose Andre PERNAMBUCO, Marta } \\
\text { Maria. ANGOTTI, Jose Andre. PERNAMBUCO, Marta Maria. Ensino de } \\
\text { ciencias: fundamentos e metodos. Sao Paulo: Cortez. }\end{array}$ \\
\hline
\end{tabular}

